\begin{tabular}{|c|c|c|}
\hline U N I V & $\begin{array}{l}\text { A N N L E } \\
\text { MARIAE C } \\
\text { BLIN - POI }\end{array}$ & \\
\hline VOL. XXXVIII & SECTIO FF & $2-2020$ \\
\hline
\end{tabular}

ISSN: 0239-426X • e-ISSN: 2449-853X • Licence: CC-BY 4.0 • DOI: 10.17951/ff.2020.38.2.9-13

\title{
The Woman and Womanhood in Literature (Introduction)
}

Kobieta i kobiecość w literaturze (wprowadzenie)

Thinking and writing about women and "womanhood" is linked to a given historical situation (cf. Borkowska, 1996) and the cultural milieu. The inability to break away from this context means that the definition of the category in question is made with reference to specific literary works. Moreover, if we take into account the complexity of women's issues as such, the variety of tools used to study it, and the functioning of "women's voice" in the space of competitive discourses with which they enter into interactive relations, it turns out that the thematic scope indicated in the title of this volume gives rise to research questions which - despite a kind of fashion for "womanhood" in scientific research - still cannot be fully answered. One may even get the impression that the more one writes about women and womanhood, the more perspectives for further research open up. What is important, as Maria Krasowska (2000, p. 205) points out:

our mentality has changed so much under the influence of the activities of feminists of both sexes that readers today are more inclined to look for the presence of women even in works that do not appear feminine and were not even written by women. This of course favours the consolidation of the image of "womanhood" as an artistic convention, which, in turn, so strengthened, becomes increasingly productive and reveals strong separatist tendencies. ${ }^{1}$

1 “czytelnicy są dziś bardziej skłonni doszukiwać się obecności kobiety nawet w dziełach, które nie wyglądają na kobiece, i nawet nie przez kobiety zostały napisane, tak dalece zmieniła się nasza mentalność pod wpływem działalności feministów obojga płci. Co oczywiście sprzyja utrwalaniu się w świadomości literackiej wizerunku „kobiecości” jako konwencji artystycznej, ta zaś z kolei tak umocniona, staje się coraz bardziej produktywna i zdradza silne tendencje separatystyczne." 
The power of "womanhood" as a research category, as evidenced by the studies and essays collected in this volume, offers an analysis and interpretation of the complex issues associated with the title categories in selected works of Polish, Russian, Belarusian, Belgian, American, French, English and Algerian literature. The impressive "geographical" horizon goes hand in hand with a broad temporal range (the texts concern literary phenomena from the first half of the $17^{\text {th }}$ century to the present).

The extensive thematic formula of this volume created an opportunity for a broad discussion, the protagonists of which are women and womanhood. The thematic issue opens with three studies of women in Old Polish literature. The subject of the first one - the article by Małgorzata Ciszewska (The Encomium of Polish Noblewomen in Jakub Sobieski's Secular Funeral Speeches [the First Half of the $17^{\text {th }}$ Century]) - are the personal models of womanhood - wives, mothers and widows - emerging from the funeral speeches of Jakub Sobieski, a prominent parliamentary speaker. The study, which offers recognition of the traits of these models, is the first to capture the issue from the perspective of nobility speeches from the first half of the $17^{\text {th }}$ century. The author draws attention to the formal exponents of the speeches and presents rhetorical techniques that allow the speaker to perform the persuasive function effectively and satisfactorily for the audience.

The second is an essay by Anna Nowicka-Struska, Description of the Journey to Vilnius of Sister Mary Magdalene of the Saviour, Anna Żaboklicka, a Discalced Carmelite Nun from Lublin. The First Polish Woman's Travel Journal from 1638. In the analysis of the manuscript, which serves as an example of applied literature (combining the journal, description and event layers), the researcher indicates, inter alia, the elimination of manifestations of individualisation, characteristic of the Discalced Carmelites, to the evolution of discourse, motivated by the framework of the journey, and to the combination of private and institutional perspectives, reserved for men's rather than women's writing. It is worth noting that the work offers an interpretation of the first Polish women's travel journal from the $17^{\text {th }}$ century.

The Old Polish "triptych" concludes with Marzena Walińska's article, entitled The Image of the Wife in the Homiletics of Antoni Wegrzynowicz. The text analyses Węgrzynowicz's sermons from the late $17^{\text {th }}$ and early $18^{\text {th }}$ centuries, which defined the position of a woman in marriage, the scope of her duties, as well as the types and ways of disciplining the fairer sex. What is worth emphasising, in contrast to the anti-woman tendencies characteristic of homiletics of the time, Węgrzynowicz - although far from being progressive - maintains moderation in his recommendations and does not depreciate womanhood.

The next text moves the audience in time and space. In her work Female Voices in Frances Sheridan's Novels: From Repression to Transgression, Valérie 
Maffre deals with the ways of expressing womanhood in the novels by the AngloIrish writer, Frances Sheridan. The rhetorical and syntactic analysis shows that the reserve manifested by the characters (in accordance with the standard of conduct prevailing and recommended in the $18^{\text {th }}$ century) is in the case of Sheridan's heroines an imposed social construct and not an innate trait of women. The act of writing becomes a space of freedom, allowing one to free one's self from reserve to subversion.

In turn, Vanesa Lado-Pazos' "Finished with All That": The Death of the Southern Lady and the Emergence of the New Woman in Ellen Glasgow's Fiction concerns the issue of womanhood examined over a longer time perspective. The essay allows us to take a look at the female characters created by the American writer, which evolve from embodying the model of a conservative Southern lady to the figure of a New Woman. The paradigm shift of the characters is accompanied at the level of poetics by a transition from sentimentalism to a realistic view of the world.

An interesting picture of womanhood emerges from the study by Magdalena Rudkowska, What is Kraszewski's Mermaid Silent about?. The scholar suggests reading the novel Piękna pani [Beautiful Lady] (original title Syrena [The Mermaid]) through the prism of feminocentric mythological themes. The silence of the protagonist of "the story-within-a-story about human passions," a character who is a forerunner of the modernist femme fatale, becomes a metaphorical expression of the experience of womanhood and, at the same time, the collective Polish experience of the $19^{\text {th }}$ century. Placing the motif of the siren in the context of Warsaw reality (the city's coat of arms) allows the researcher to go beyond an interpretation that considers sexuality and carnality, and to offer a look within the order of the civilisational and urban metaphor.

Tadeusz Budrewicz's essay Elżbieta Oraczowa / Elizaweta Oracz. Eugenia Żmijewska in Relation to Eliza Orzeszkowa brings a fascinating two-level analysis of the relations between two $19^{\text {th }}$-century women writers important for Polish culture. The researcher, referencing correspondence, critical land literary articles, memoirs and novels (Orzeszkowa's Dwa spotkania [Two Meetings] and Żmijewska's Jutro [Tomorrow], the protagonist of the latter being based on Orzeszkowa), proves that through the literary creation of a character based on the real-life Orzeszkowa, Żmijewska tries to express her own views. The Siberianness emphasised in the study, as an experience of disinheritance and loss, allows for a better reading of the nature of Orzeszkowa's message (the formula of the civic deed) given to Żmijewska.

A woman's perspective on the perception of exotic womanhood comes from the study by Anne-Aurélie Seya-Grondin, Meet the "Mousmé." The Otherness of the Japanese Woman in the Writings of French Women Travellers of the First Half 
of the $20^{\text {th }}$ Century, who deals with French women's travel writing from the late $19^{\text {th }}$ and early $20^{\text {th }}$ centuries (including Arlette Leroi-Gourhan and Geneviève Morita). The researcher tries to point out traces of male travellers' discourse in the French women's accounts, and at the same time reconstruct the specificity of women's writing about exotic, culturally different womanhood.

In her study The Image of Maria Lazich in Afanasy Fet's Prose Memoirs, Joanna Dziedzic presents the relations between the biography of the title character and the character of Elena Larina, created by the writer. She traced the nature of the relationship between people with similar sensitivity, aesthetic, and literary preferences, as well as the traces of their biographical experience and fascination (for example, with Georgesandism) in Fet's narrative.

In the essay The Poetic World of Nadezhda Artymovich and Mira Luksha. Similarities and Dissimilarities, Halina Twaranowicz took up the subject of Belarusian women's poetry of the title artists (who also write in Polish). The article points out the similarities and differences in the creation of a poetic reality, the methods of imaging the artists use, as well as the realised forms of expression and aesthetic preferences. The author also discusses the functioning of Belarusian poetry in the space of and in relation to Polish tradition (both artists were associated with the "Białowieża" Belarusian Literary Association which operated in Białystok). The researcher proposes looking at contemporary Belarusian women's lyricism from a new perspective.

The semantic horizon of Aleksandra Szester's text, Women, Cats, the Moon. About Leo Lipski's Prose, is determined by representations of women in Lipski's modern emigration prose, related to the hydrological, lunar and animalistic topics. The essay presents reformulated stereotypes of gender differences typical of misogynist male discourse that form a complex symbolic structure, leading to the conclusion that Lipski suggests a reinterpretation of the femme fatale motif in his works.

Alicja Świca deals with the small narrative forms of American writer Shirley Jackson in her text The Spectral Presence of the (Un)dead Mother in Shirley Jackson's Short Stories. Using tools borrowed from psychoanalysis and drawing on the myth of Persephone, the author attempts to trace mother-daughter relations in the stories The Daemon Lover and The Tooth, to bring closer the character and personality-identity causes of female characters' blocks.

In the study Creative Paratopy in "Nulle autre voix" by Maïssa Bey, Mohammed Rachid Beneddra uses the category of paratopy to analyse the experience of women's imprisonment and crime shown in the novel, read - as proposed by Dominique Maingueneau - through the context present in the text (and not external to it). Entering the field of cultural discourse, the reader has the opportunity to experience reality in a more profound way. 
The issue of womanhood in the short stories of Belgian writer Anne Richter, analysed through references to the theoreticians of fantasy literature and the assumptions of the feminist critique of Hélène Cixous, Simone de Beauvoir and Julia Kristeva, was taken up by Agnieszka Loska in The Extraordinary Feminine Nature in Anne Richter's Fantastic Stories. The researcher attempted to present fantastic animal and plant metamorphosis as a tool used not only to arouse fear in the reader but also as a positive value (liberation from the monotony of life) and an invitation to reflect on the condition of women.

Observations on contemporary American literature related to the main theme of this volume can be found in Fella Benabed's essay Indigenous Ecofeminism and Literature of Matrilineage in Linda Hogan's "Solar Storms." In the text, the reader can trace the symbolic links of women and womanhood with nature, as well as observe how intergenerational trauma becomes an experience strengthening the collective.

Dora Leontaridou's article Valorisation of Mythological Female Characters in the Writings of Azama, Huston, Lemoine, and Py, at the Turn of the Century (1980-2020) is devoted to contemporary French and Francophone drama writing. Starting with an ancient model, the researcher analyses selected theatrical plays from the last 40 years (written by Michel Azama, Nancy Huston, Jean-René Lemoine, Olivier Py), trying to show the methodology of contemporary redefinition of myths related to female characters.

The articles collected in the themed issue of the Annales UMCS. Sec. FF, written by both mature researchers and young adepts of humanities is another voice in the discussion of women and womanhood, a voice that we hope will encourage further studies.

Constante González Groba, Monika Gabryś-Stawińska

\section{REFERENCES}

Borkowska, Grażyna. (1996). Cudzoziemki. Studia o polskiej prozie kobiecej. Warszawa: Wydawnictwo Instytutu Badań Literackich PAN.

Kraskowska, Ewa. (2000). O tak zwanej „kobiecości” jako konwencji literackiej. In: Grażyna Borkowska, Liliana Sikora (eds.), Krytyka feministyczna: siostra teorii i historii literatury (pp. 200-212). Warszawa: Wydawnictwo Instytutu Badań Literackich PAN. 